\title{
Identifikasi cacat lintasan luar bantalan bola menggunakan Support Vector Machine (SVM) pada fan industri
}

\author{
Berli P. Kamiel ${ }^{1 *}$, Wildan T. B. Anggoro ${ }^{2}$, Bambang Riyanta ${ }^{3}$ \\ Jurusan Teknik Mesin, Fakultas Teknik, Universitas Muhammadiyah Yogyakarta 1,2,3 \\ Jl. Brawijaya, Tamantirto, Kasihan, Bantul, Yogyakarta \\ E-mail: berlikamiel@umy.ac.id ${ }^{1}$, wildtop131@gmail.com², bambangriyanta@umy.ac.id ${ }^{3}$
}

\begin{abstract}
Air regulation creates a comfortable and healthy environment for activities in the industry. A fan is a rotary machine that functions to regulate and circulate air in a room or work area. The bearing is an important component of a fan that is potentially damaged during operation. Damage to the bearing will interfere with perform the fan and can even disrupt a whole production process. A bearing condition monitoring method is needed that is effective and easy to use. Conventional methods such as spectrum analysis and sound analysis are not easy to use by operators in the field due to spectrum analysis requires spectrum reading experience while sound analysis is highly dependent on personal experience. This study proposes a vibration-based pattern recognition method that is Support Vector Machine (SVM) to detect damage to a bearing. This method effectively classifies bearing conditions and is easy to use. The study aims to obtain a method of detecting defects in single-row bearing outer paths on industrial fans using SVM. The study uses an industrial fan test rig with two bearing conditions, that is normal conditions (no defects) and external track defects with a depth of 1.4 $\mathrm{mm}$ defect and $0.4 \mathrm{~mm}$ width. Recording vibration signals using a data acquisition module with a sampling speed of $17066 \mathrm{~Hz}$ and a motor rotational speed of $2850 \mathrm{rpm}$. The SVM classifier is trained using 9 selected statistical parameters which are extracted from 700 sets of vibration signal recordings. The results showed the statistical parameters that were effectively used were Root Mean Square (RMS), Standard Deviation, Kurtosis, Variance, Entropy, Standard Error, Median, Signal-to-Noise and Distortion Ratio (SINAD), and Signal to Noise Ratio (SNR). The most optimal SVM model is obtained by applying combine Median-SINAD statistical parameters, with the same testing accuracy for the RBF, Polynomial and Linear kernels at $100 \%$.
\end{abstract}

Keywords: Bearings, external path defects, kernel, statistical parameters, SVM.

\begin{abstract}
Abstrak
Pengaturan udara menciptakan lingkungan yang nyaman dan sehat dalam aktivitas di sebuah industri. Fan adalah salah satu mesin rotari yang berfungsi mengatur dan mensirkulasikan udara di suatu ruangan atau area kerja. Bantalan adalah komponen penting pada sebuah fan yang berpotensi rusak pada saat beroperasi. Kerusakan pada bantalan akan mengganggu kinerja dari fan bahkan dapat mengganggu suatu proses produksi secara keseluruhan. Diperlukan metode pemantauan kondisi sebuah bantalan yang efektif dan mudah digunakan. Metode konvensional seperti analisis spektrum dan analisis suara tidak mudah digunakan oleh operator di lapangan karena analisis spektrum membutuhkan keahlian membaca spektrum sedangkan analisis suara sangat tergantung pada pengalaman personal. Penelitian ini mengusulkan metode pengenalan pola (pattern recognition) berbasis getaran yaitu Support Vector Machine (SVM) untuk mendeteksi kerusakan sebuah bantalan. Metode ini efektif mengklasifikasi kondisi bantalan dan mudah digunakan. Tujuan penelitian adalah untuk menghasilkan metode deteksi cacat bantalan lintasan luar bantalan tipe single row pada fan industri dengan menggunakan SVM. Penelitian menggunakan rig uji fan industri dengan
\end{abstract}


dua kondisi bantalan yaitu kondisi normal (tidak cacat) dan cacat lintasan luar dengan kedalaman cacat 1,4 $\mathrm{mm}$ dan lebar $0,4 \mathrm{~mm}$. Perekaman sinyal getaran menggunakan modul akuisisi data dengan kecepatan sampling $17.066 \mathrm{~Hz}$ dan kecepatan putar motor $2.850 \mathrm{rpm}$. Classifier SVM dilatih menggunakan 9 parameter statistik terpilih yang diekstrak dari 700 set rekaman sinyal getaran. Hasil penelitian menunjukan parameter statistik yang efektif digunakan adalah Root Mean Square (RMS), Standar Deviasi, Kurtosis, Variance, Entropy, Standard Error, Median, Signal-to-Noise and Distortion Ratio (SINAD), dan Signal to Noise Ratio (SNR). Model SVM paling optimal didapatkan dengan menerapkan kombinasi parameter statistik Median-SINAD, dengan akurasi pengujian yang sama untuk kernel radial basis function (RBF), Polynomial, dan Linier sebesar $100 \%$.

Kata kunci: Bantalan, cacat lintasan luar, kernel, parameter statistik, SVM.

\section{Pendahuluan}

Fan adalah mesin rotari yang berfungsi mengatur sirkulasi udara pada suatu area. Salah satu komponen penting pada sebuah fan adalah bantalan yang berfungsi menopang beban radial dan mengurangi gesekan elemen yang berputar. Pembebanan terus menerus menyebabkan bantalan mengalami penurunan kondisi sehingga dapat terbentuk cacat pada elemen bantalan. Cacat tersebut berpotensi menurunkan performa fan bahkan dapat mengganggu proses produksi secara keseluruhan. Oleh karena itu pemantauan kondisi bantalan yang mudah dan efektif perlu dilakukan. Deteksi kerusakan/cacat sebuah komponen mesin menggunakan sinyal getaran telah banyak diteliti. Anoi dkk [1] menyatakan bahwa observasi getaran pada peralatan berputar (rotating equipment) perlu dilakukan untuk mendeteksi potensi permasalahan pada peralatan tersebut. Menurut Kamiel dkk [2] metode berbasis getaran seperti analisis spektrum efektif mendeteksi cacat bantalan pada sebuah pompa sentrifugal. Namun pada kondisi cacat awal (early fault) identifikasi amplitudo pada frekwensi cacat bantalan sulit dilakukan. Hal ini disebabkan energi impak antara elemen bantalan dan lokasi cacat masih sangat kecil yang berakibat amplitudonya sangat rendah. Pada spektrum, amplitudo rendah ini tertutup oleh amplitudo noise dan amplitudo lain yang lebih tinggi. Deteksi cacat bantalan pada kondisi ini menjadi tidak mungkin dilakukan oleh spektrum.
Selain itu analisis spektrum membutuhkan operator yang terlatih membaca dan menafsirkan spektrum.

Dibutuhkan metode deteksi cacat bantalan yang efektif dan mudah digunakan oleh operator di lapangan. Metode klasifikasi dengan pengenalan pola (pattern recognition) telah banyak diterapkan di berbagai bidang seperti ditunjukkan pada Tabel 1. Metode ini akurat dan mudah digunakan oleh operator tanpa keahlian khusus tentang karakteristik getaran. Salah satu algoritma metode pengenalan pola adalah SVM. Classifier SVM dapat mendeteksi cacat pada bantalan dengan mengklasifikasi sinyal getaran bantalan normal (tanpa cacat) dan sinyal getaran bantalan cacat. Kelebihan dari metode ini adalah kemampuan generalisasi yang baik.

Salah satu tahap penting saat melatih classifier SVM adalah pemilihan kernel. Penelitian yang dilakukan oleh Fathurrohman dkk [3] menunjukkan fungsi kernel terbaik adalah radial basis function (RBF) dengan akurasi training 98,9\% dan testing $97,5 \%$.

Walaupun SVM telah banyak digunakan dalam mengklasifikasi berbagai objek namun tidak terdapat standar baku dalam menentukan jenis parameter input yang digunakan dalam melatih classifier SVM, hal ini dapat dilihat pada Tabel 1 dimana parameter statistik yang digunakan bervariasi. Terdapat celah penelitian yang masih dapat di-eksplorasi yaitu jenis parameter statistik yang efektif untuk melatih classifier SVM. 
Tabel 1. Parameter statistik yang sering digunakan

\begin{tabular}{|c|c|c|}
\hline Penulis & Objek & $\begin{array}{l}\text { Parameter } \\
\text { Statistik }\end{array}$ \\
\hline $\begin{array}{l}\text { Sakhtivel } \\
\text {, dkk [4] }\end{array}$ & $\begin{array}{l}\text { Pompa } \\
\text { Sentrifug } \\
\text { al }\end{array}$ & $\begin{array}{l}\text { Mean, Median, } \\
\text { Standard } \\
\text { Deviation, } \\
\text { Standard } \\
\text { Error, Variance, } \\
\text { Skewness, } \\
\text { Kurtosis, } \\
\text { SUM, Range, } \\
\text { Minimum, } \\
\text { Maximum }\end{array}$ \\
\hline $\begin{array}{l}\text { Perdana, } \\
\text { dkk [5] }\end{array}$ & Jantung & SNR dan SINAD \\
\hline $\begin{array}{l}\text { Mahendr } \\
\text { a, dkk } \\
\text { [6] }\end{array}$ & Kayu & $\begin{array}{l}\text { mean, skewness, } \\
\text { variance, } \\
\text { kurtosis, dan } \\
\text { entropy }\end{array}$ \\
\hline $\begin{array}{l}\text { Luo, dkk } \\
\text { [7] }\end{array}$ & $\begin{array}{l}\text { Pompa } \\
\text { Sentrifug } \\
\text { al }\end{array}$ & $\begin{array}{l}\text { RMS, Crest } \\
\text { Factor, Peak, } \\
\text { PDF }\end{array}$ \\
\hline $\begin{array}{l}\text { Fathurro } \\
\text { hman, } \\
\text { dkk [3] }\end{array}$ & $\begin{array}{l}\text { Bantalan } \\
\text { Bola }\end{array}$ & $\begin{array}{l}\text { RMS, Standard } \\
\text { Deviation, } \\
\text { Variance, } \\
\text { Crest-Factor, } \\
\text { Shape-Factor, } \\
\text { Kurtosis, } \\
\text { Skewness, } \\
\text { Entropy }\end{array}$ \\
\hline
\end{tabular}

Tujuan dari penelitian ini adalah mendeteksi cacat bantalan bola lintasan luar pada fan industri berbasis classifier SVM menggunakan input parameter statistik yang dipilih.

\section{Tinjauan Pustaka}

\section{Jenis kerusakan bantalan}

Kerusakan pada bantalan dapat mengganggu fungsi dan performanya. Kerusakan dapat diakibatkan oleh beban berlebih, kontaminasi material asing, pemasangan yang kurang tepat, keausan, retak, pemberian pelumas yang tidak sesuai, kerusakan saat pembuatan komponen, dan perbedaan diameter bola [8]. Beberapa jenis kerusakan elemen bantalan yang sering dijumpai adalah:
1. Cacat lintasan dalam

Cacat lintasan dalam diakibatkan karena adanya aus maupun kerusakan kecil yang membesar karena beban dan gesekan yang terjadi saat bantalan beroperasi. Cacat lintasan dalam menghasilkan modulasi amplitudo akibat dari berpindahnya lokasi cacat dari dan ke zona pembebanan (loading zone).

2. Cacat lintasan luar

Cacat lintasan luar terjadi karena adanya kerusakan kecil yang membesar maupun kurangnya pelumasan yang menyebabkan keausan. Kerusakan pada lintasan luar cenderung akan memberi dampak secara cepat pada kondisi elemen lintasan dalam [9]. Cacat lintasan luar menimbulkan gaya eksitasi karena adanya benturan maupun gesekan antara elemen bola dan lokasi cacat bola [10].

\section{Support Vector Machine (SVM)}

SVM adalah metode yang berguna dalam klasifikasi biner yang Pertama kali dikenalkan oleh Vapnik ditahun 1992 bersama Isabelle Guyon dan Bernhard Boser dengan menyatukan sejumlah rangkaian konsep dibidang Pattern Recognition. Pattern Recognition merupakan metode yang digunakan untuk memetakan sejumlah data kedalam konsep yang telah ditentukan sebelumnya. Pada dasarnya SVM bekerja dengan linear classifier yang kemudian dikembangkan supaya dapat digunakan dalam persoalan non-linear dengan menggabungkan konsep kernel trick dalam ruang kerja yang memiliki dimensi tinggi [11]. Penjelasan sederhana dari Konsep SVM adalah mencari hyperplane terbaik yang digunakan untuk memisahkan dua buah kelas pada input space [12].

Hyperplane yang berada ditengah antara dua set objek dari dua kelas merupakan hyperplane terbaik seperti ditunjukkan pada Gambar 1. Mencari hyperplane terbaik dilakukan dengan membentuk beberapa batas diskriminasi (alternatif garis pemisah), menemukan titik tertinggi dan mencari marginnya. 


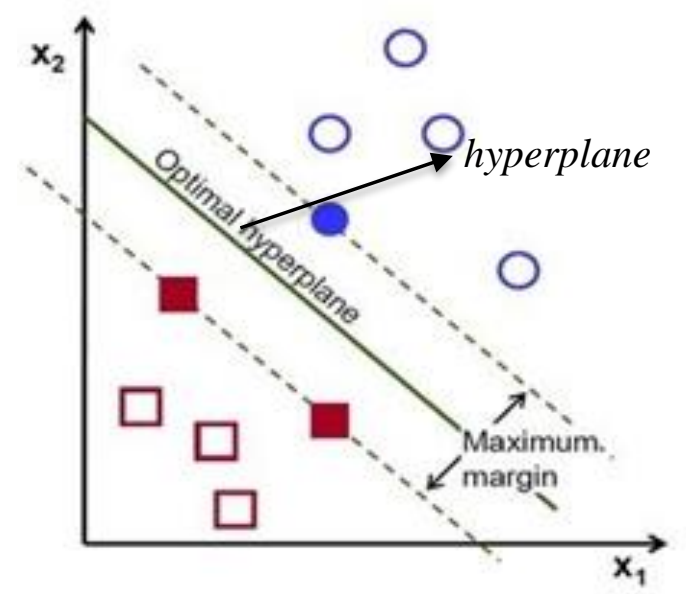

Gambar 1. Hyperplane Terbaik

\section{Kernel Function}

Kernel Function adalah metode yang berfungsi untuk memetakan sejumlah data kedalam kinerja fitur dimensi yang lebih tinggi. Dengan demikian data hasil yang didapatkan tidak memerlukan evaluasi lanjut kedalam ruang kerja berdimensi tinggi, hal tersebut dapat menjadi solusi dalam keterbatasan dimensi. Dengan melakukan pendekatan Kernel Function hasil data dalam fitur dimensi tinggi akan ekuivalen dengan data dalam ruang input.

Fungsi kernel yang biasa digunakan dapat dilihat pada Tabel 2.

Tabel 2. Fungsi Kernel

\begin{tabular}{cc}
\hline Fungsi Kernel & Rumus Fungsi \\
\hline Linier & $x^{T} x^{\prime}$ \\
\hline$R B F$ & $\exp \left(-\frac{\left\|x-x^{\prime}\right\|^{2}}{2 \sigma^{2}}\right)$ \\
\hline Polynomial & $\left(x, x^{\prime}\right)^{d}$ \\
\hline
\end{tabular}

\section{Parameter Statistik}

Parameter statistik yang diseleksi untuk menjadi input dalam melatih classsifier SVM adalah:

\section{Root Mean Square (RMS)}

RMS dirumuskan sebagai akar kuadrat dari rata-rata nilai kuadrat dari gelombang sinyal getaran.

2. Standar Deviasi (SD)
Standar deviasi menunjukkan tingkat energi yang terkandung dalam sinyal getaran. Semakin besar nilai parameter SD, maka energi atau daya yang ditimbulkan semakin tinggi.

\section{Variance}

Variance adalah parameter statistik yang menunjukkan seberapa jauh kumpulan data tersebar yang dirumuskan sebagai nilai kuadrat dari nilai standar deviasinya.

\section{Kurtosis}

Kurtosis adalah parameter yang menunjukkan nilai kelancipan dan kedataran relatif sebuah distribusi dibanding distribusi normal sinyal.

\section{Standard Error (SE)}

Standard Error merupakan standar deviasi dari rata-rata. Bila kita punya sekelompok data, contohnya tiga kelompok, maka kita akan mendapat tiga buah dari nilai rata-rata. jika dihitung nilai standar deviasi dari tiga buah dari nilai ratarata tersebut, maka nilai standar deviasi dari nilai rata-rata tersebut disebut nilai standar error.

\section{Minimum Value}

Minimum Value menggambarkan titik terendah dari data yang dihasilkan dari suatu kelompok data.

\section{Crest Factor}

Crest factor diartikan sebagai rasio dari nilai tertinggi dari sinyal masukan terhadap nilai RMS

\section{Peak Value}

Peak value merupakan parameter statistik yang digunkan sebagai penunjuk indeks intensitas energi pada sinyal getaran, nilai parameter ini bersifat konstan terhadap laju aliran.

\section{Entrophy}

Entrophy adalah fungsi distribusi suatu sistem pada kondisi mikro. Nilai entropy adalah ukuran kuantitatif yang menggambarkan ketidakteraturan dari suatu sistem.

\section{Mean}

Mean adalah nilai yang yang didapat dari nilai rata-rata kelompok tersebut. RataRata (mean) diperoleh dengan menjumlah 
seluruh data individu dalam kelompok, kemudian dibagi dengan banyaknya individu yang terdapat kelompok data tersebut.

\section{Skewness}

Skewness menunjukkan tingkat kesimetrisan distribusi disekitar daerah rata-ratanya. Skewness disebut juga tingkat kemiringan, yaitu bilangan yang dapat menggambarkan bentuk kurva suatu distribusi berdasarkan miring atau tidaknya kurva tersebut.

\section{Maximum Value}

Minimum Value menggambarkan titik tertinggi dari data yang dihasilkan dari suatu kelompok data.

\section{SUM}

SUM adalah parameter statistik yang menunjukkan nilai penjumlahan dari suatu data. Baik data individu maupun kelompok.

\section{Median}

Median merupakan parameter statistik yang menunjukkan nilai tengah dari suatu kelompok data. Jika sekelompok data diurutkan dari data terkecil hingga terbesar atau sebaliknya, maka nilai median didapat dari pengamatan data yang tepat berada di tengah-tengah data ganjil, atau rata-rata dari kedua pengamatan yang berada di tengah data berjumlah genap.

\section{Signal-to-Noise and Distortion Ratio} (SINAD)

SINAD adalah ukuran kualitas sinyal dari suatu data.

\section{Signal to Noise Ratio (SNR)}

SNR adalah perbandingan (ratio) dari kekuatan Sinyal (signal strength) terhadap kekuatan derau (noise level). Nilai SNR digunakan untuk menggambarkan kualitas dari suatu data. Semakin tinggi nilai $S N R$, semakin tinggi kualitas data tersebut.

\section{Range}

Rentang (range) atau jangkauan merupakan nilai selisih dari data nilai terbesar dengan data nilai yang terkecil dari suatu kelompok data. Atau dapat diartikan Range didapatkan dengan melakukan pengurangan dari data nilai maksimum dengan data nilai minimum.

\section{Metode Penelitian}

Metode yang diusulkan diverifikasi menggunakan rig uji yang secara skematik ditunjukkan pada Gambar 2. Rig uji terdiri dari komponen-komponen seperti motor listrik AC $1 \mathrm{HP}$, pasangan roda gigi, sabuk -puli, bantalan, poros dan bilah fan. Bantalan yang digunakan adalah tipe bantalan bola single row merk ASB tipe 6209. Ada dua kondisi bantalan yang digunakan yaitu kondisi normal (tidak cacat) ditunjukkan pada Gambar 3. dan kondisi cacat lintasan luar, Gambar 4. Bantalan cacat dibuat menggunakan proses EDM dengan lebar cacat 0,4 mm dengan kedalaman 1,4 mm. Perekaman sinyal getaran arah radial dilakukan menggunakan akselerometer uniaksial dari Bruel \& Kjaer tipe 4507 B yang diletakkan pada rumah bantalan. Sebuah modul data akuisisi 24 bit dari National Instrument NI 9234 digunakan untuk proses akuisisi dengan kecepatan sampling 17066 Hz. Kecepatan bantalan uji dijaga konstan pada 550 RPM $(9,16 \mathrm{~Hz})$.

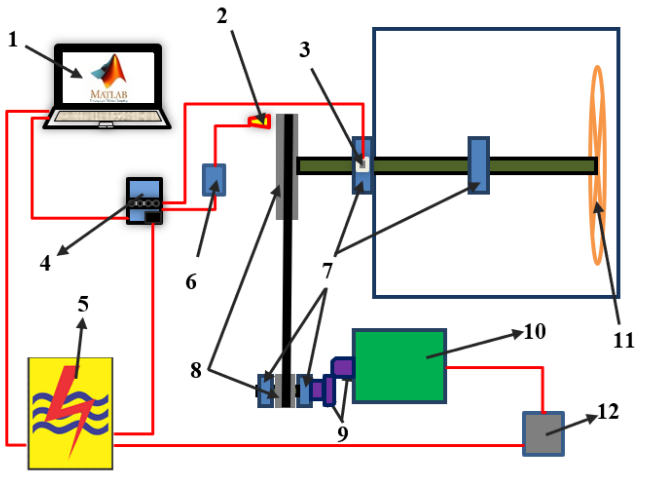
1. Laptop
7. Bantalan
2. Sensor Proximity
8. Puli
3. Akselerometer
9. Roda gigi
4. Modul DAQ
10. Motor AC
5. Sumber Listrik
11. Bilah Fan
6. Arduino UNO
12. Saklar

\section{Gambar 2. Skema Alat Uji}




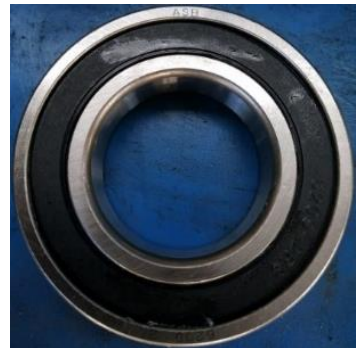

Gambar 3. Bantalan Normal

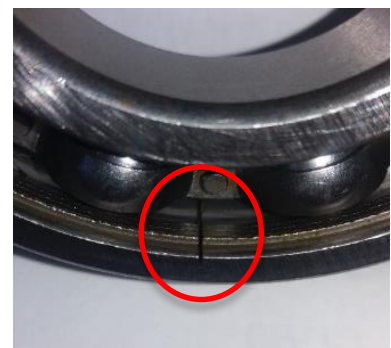

Gambar 4. Bantalan Cacat Lintasan Luar

Akuisisi data sinyal getaran dilakukan untuk masing-masing kondisi bantalan selama 10 detik dengan kecepatan sampling $17066 \mathrm{~Hz}$. Hasil rekaman adalah 700 set data untuk masing-masing kondisi yang dibagi menjadi 2 bagian yaitu untuk proses training sebanyak 500 set data dan untuk proses testing adalah 200 set data.

Secara umum analisis sinyal getaran dilakukan menggunakan dua metode yaitu domain waktu dan domain frekuensi (spektrum). Plot domain waktu untuk $2 \mathrm{x}$ putaran poros dapat dilihat pada Gambar 5 sedangkan plot spektrum ditunjukkan pada Gambar 6. Fast Fourier Transform (FFT) digunakan untuk mentransformasikan sinyal domain waktu menjadi spektrum dimana secara teori frekwensi karakteristik bantalan cacat seperti BPFO dan BPFI dapat diidentifikasi. Namun demikian seperti dapat dilihat pada Gambar 6, relatif sulit mengidentifikasi bantalan normal dan cacat dari spektrumnya.

\section{Classifier $\boldsymbol{S V M}$}

Classidier SVM memerlukan input parameter statistik untuk mengklasifikasi kondisi bantalan. Tujuh belas parameter statistik yaitu Standard Deviation (SD), Root Mean Square (RMS), Peak Value, Kurtosis, Crest Factor, Variance, Mean, Entropy, Minimum Value, Standard Error (SE), Skewness, Maximum Value, Range,
Sum, Median, Signal to Noise and Distortion Ratio (SINAD), dan Signal to Noise Ratio (SNR) diekstrak dari domain waktu. Sebelum diputuskan untuk menjadi input SVM, ketujuhbelas parameter statistik tersebut diseleksi secara visual. Seleksi visual dilakukan dengan cara membuat scatter plot masig-masing nilai parameter statistik kondisi normal dan kondisi cacat. Scatter plot yang secara visual terlihat batas yang jelas antara data dari bantalan normal dan cacat dipilih sebagai input SVM. Hasil seleksi visual dirangkum pada Tabel 3.

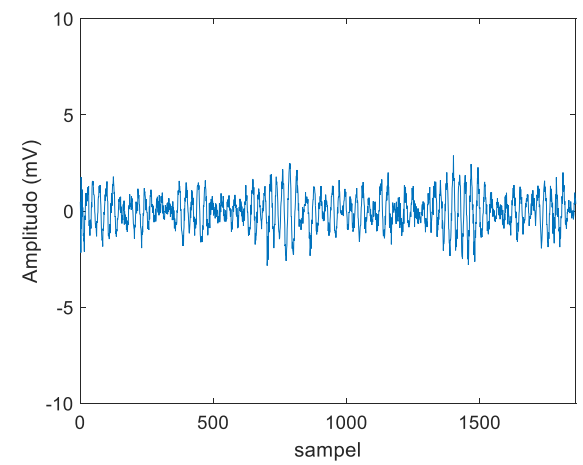

(a)

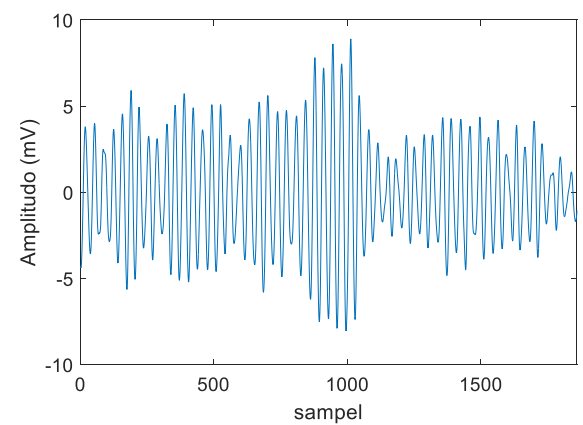

(b)

Gambar 5. Domain waktu (a) bantalan normal (b) bantalan cacat Lintasan Luar

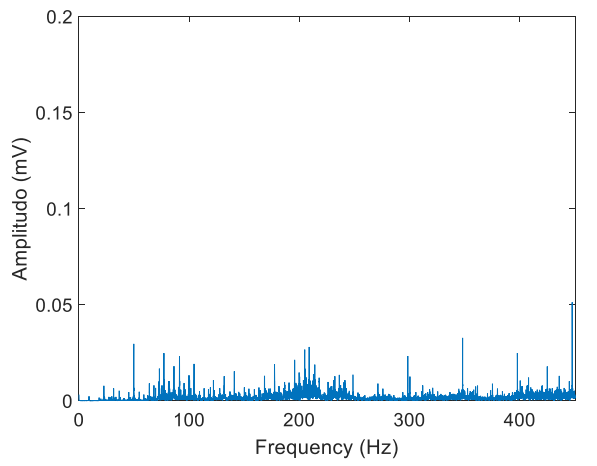

(a) 


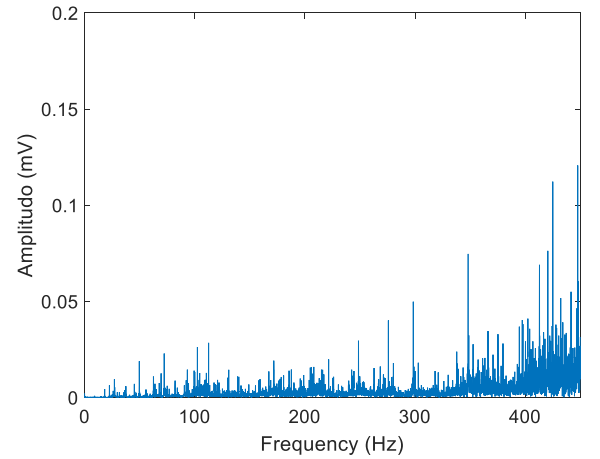

(b)

Gambar 5. Spektrum (a) bantalan normal

(b) bantalan cacat lintasan luar

\section{Hasil dan Pembahasan}

Meningkatnya level getaran menyebabkan meningkatnya amplitudo pada domain waktu. Hal ini dapat dilihat dengan membandingkan Gambar 5(a) bantalan normal dengan Gambar 5(b) bantalan cacat. Amplitudo yang dihasilkan oleh bantalan cacat terlihat jelas lebih tinggi dibandingkan dengan amplitudo bantalan normal. Menurut Susilo [13] bantalan cacat lintasan luar menimbulkan benturan dari permukaan lintasan dengan bola yang berputar sehingga menghasilkan impak yang besarnya sebanding dengan lebar cacat sedangkan frekuensi impak dapat ditentukan dengan menghitung BPFO. Impak juga akan mengeksitasi frekwensi natural bantalan dan menghasilkan frekwensi tinggi. Namun demikian identifikasi cacat bantalan sulit dilakukan di domain waktu karena peningkatan amplitudo dapat disebabkan oleh banyak sebab, tidak hanya disebabkan oleh cacat bantalan.

Tabel 3 Seleksi Visual Parameter Statistik

\begin{tabular}{|c|c|}
\hline Parameter Statistik & Hasil Analisis Visual \\
\hline $\begin{array}{lr}\text { RMS, Standar Deviasi, } \\
\text { Kurtosis, } \quad \text { Variance, } \\
\text { Entropy, } \quad \text { Standard } \\
\text { Error, } \quad \text { Median, } \\
\text { SINAD, SNR }\end{array}$ & $\begin{array}{l}\text { Dapat memisahkan data } \\
\text { getaran bantalan normal } \\
\text { dengan data getaran } \\
\text { bantalan cacat dengan } \\
\text { baik }\end{array}$ \\
\hline $\begin{array}{l}\text { Peak Value, Crest } \\
\text { Factor, Minimum, } \\
\text { Skewness, Maximum, } \\
\text { Range }\end{array}$ & $\begin{array}{l}\text { Terdapat tumpang } \\
\text { tindih data (overlap) }\end{array}$ \\
\hline Mean, SUM & $\begin{array}{l}\text { Tidak dapat } \\
\text { memisahkan data }\end{array}$ \\
\hline
\end{tabular}

Cacat bantalan akan menghasilkan frekwensi karakteristik yang disebut BPFO untuk cacat lintasan dalam. Amplitudo BPFO akan tinggi pada spektrum jika terjadi cacat lintasan luar pada bantalan. Namun demikian amplitudo BPFO tidak selalu terlihat jelas, seperti ditunjukkan pada Gambar 6(a) dan 6(b). Hal ini sering terjadi pada mesin-mesin rotari yang mempunyai gearbox dimana amplitudo gear mesh frequency (GMF) beserta harmonik dan sidebands-nya jauh lebih besar sehingga amplitudo BPFO terbenam dan sulit diobservasi.

SVM menggunakan pendekatan pengenalan pola yang tidak memerlukan observasi amplitudo BPFO pada spektrum. Metode ini relatif lebih mudah digunakan oleh operator yang tidak mempunyai keterampilan dan pengalaman membaca spektrum.

Classifier SVM dilatih menggunakan 9 parameter statistik yang dipilih berdasarkan seleksi visual terbaik. Lima ratus set data digunakan pada proses training ini. Hasil training kesembilan parameter tersebut kemudian dipilih dua parameter yang menghasilkan kombinasi terbaik dalam memisahkan data getaran bantalan normal dengan data getaran bantalan cacat. Kombinasi tersebut adalah: Kurtosis-Variance, Entropy-Standard Error, dan Median-SINAD. Tiga kernel yaitu RBF, linier dan polinomial digunakan dalam proses training classifier SVM untuk masing-masing kombinasi parameter tersebut.

Hasil klasifikasi data menggunakan kombinasi Kurtosis-Variance ditunjukkan pada Gambar 7. Klasifikasi data training dapat dilihat pada Gambar 7(a) dan klasifikasi data testing ditunjukan pada Gambar 7(b). Kombinasi Entropy-Standard Error (SE) ditunjukkan pada Gambar 8 sedangkan kombinasi Median-SINAD dapat dilihat pada Gambar 9.

Semua kombinasi parameter statistik menunjukkan bahwa pola pemisahan kondisi normal dan kondisi cacat adalah identik antara data training dan data testing. 
Hal tersebut dikarenakan proses testing tidak membangun model baru tetapi menempati model yang sudah dibuat dalam proses training.

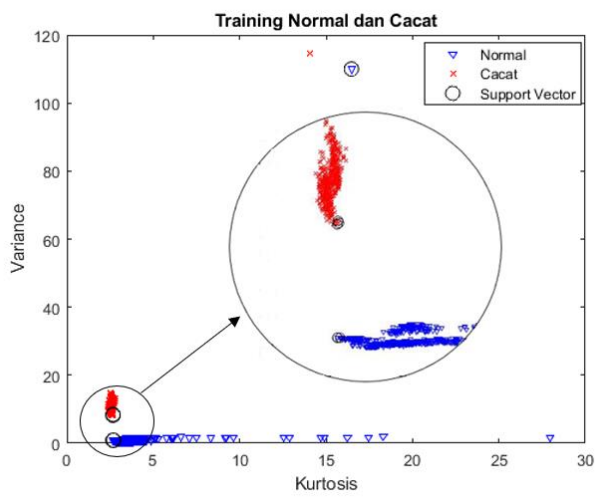

(a)

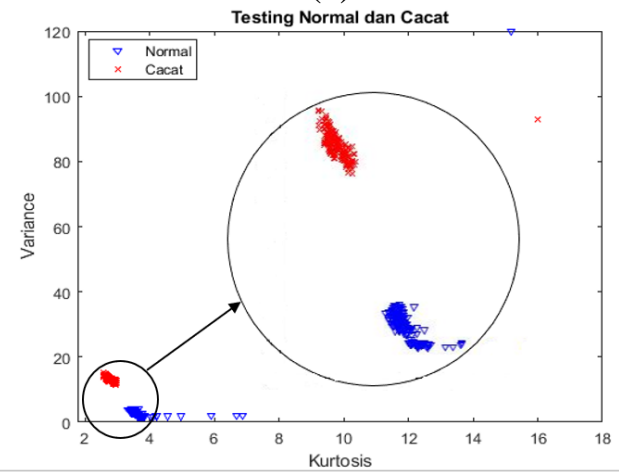

(b)

Gambar 7. (a) Klasifikasi data training (b) klasifikasi data testing kombinasi Kurtosis-Variance

Kombinasi Kurtosis-Variance menggunakan kernel RBF menghasilkan klasifikasi yang efektif dimana kondisi normal dan cacat terpisah dengan jelas tanpa terjadi overlap, sedangkan penggunaan kernel linier dan polinomial terjadi sedikit salah klasifikasi. Akurasi SVM dengan kernel RBF adalah 100\% yang bermakna tidak terjadi kesalahan klasifikasi untuk semua (200 data) testing, sedangkan dua kernel lainnya terjadi kesalahan klasifikasi yaitu sebesar $0,25 \%$. Namun demikian dapat dinyatakan bahwa ketiga kernel tersebut memberikan akurasi klasifikasi yang tinggi untuk classifier SVM yang menggunakan input kombinasi parameter Kurtosis-Variance.

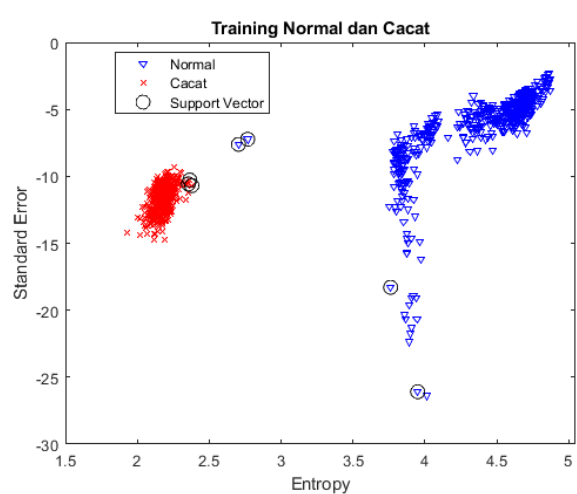

(a)

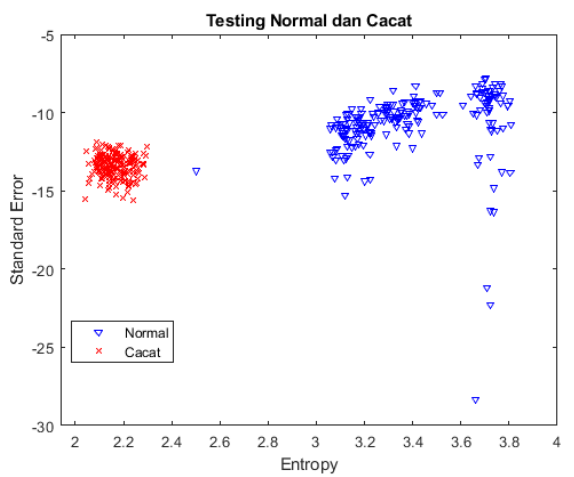

(b)

Gambar 8. (a) Klasifikasi data training (b) klasifikasi data testing kombinasi Entropy dan Standard Error.

Hasil klasifikasi SVM menggunakan kombinasi Entropy-Standard Error pada Gambar 8 menujukkan efek clustering yang nyata dimana data bantalan normal dan data bantalan cacat dipisahkan dengan jelas. Kombinasi parameter ini memberikan tingkat akurasi tertinggi pada penggunaan kernel polinomial yaitu $100 \%$. Kesalahan klasifikasi yang relatif kecil yaitu $0,25 \%$ terjadi pada kernel RBF dan linier.

Gambar 9 menunjukkan hasil klasifikasi kombinasi parameter MedianSINAD dimana data bantalan normal dan data bantalan cacat terpisah jelas dengan margin paling lebar dibandingkan dua kombinasi sebelumnya. Tingkat akurasi untuk tiga buah kernel pada kombinasi Median-SINAD adalah $100 \%$, yang artinya tidak terjadi kesalahan klasifikasi untuk semua data testing. Margin yang lebar membuat classifier relatif lebih kebal terhadap variasi data sehingga kesalahan klasifikasi menjadi minimal. Rangkuman tingkat akurasi classifier untuk masing- 
masing kombinasi parameter statistik dapat dilihat pada Tabel 4.

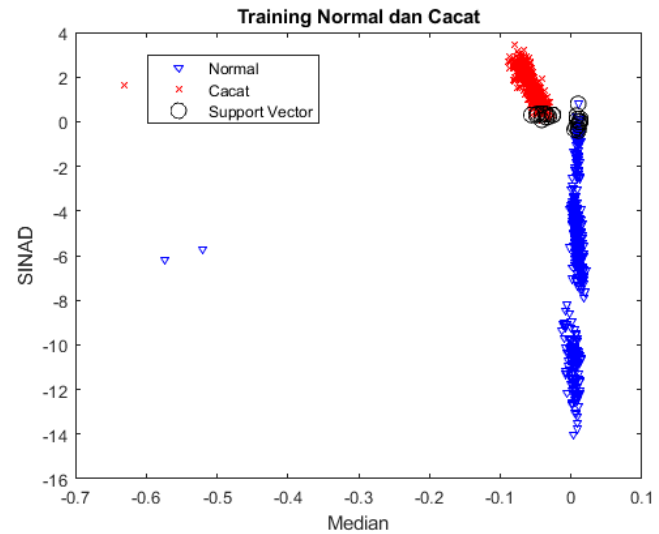

(a)

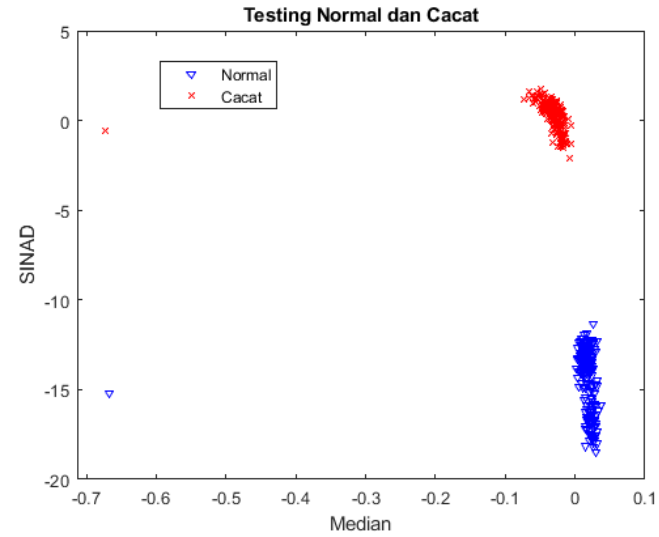

(b)

Gambar 9. (a) Klasifikasi data training (b) klasifikasi data testing kombinasi Median dan SINAD

Tabel 4 Akurasi klasifikasi kombinasi parameter statistik

\begin{tabular}{lccc}
\hline & \multicolumn{3}{c}{ Akurasi (\%) } \\
\cline { 2 - 4 } Kombinasi & RBF & Linier & $\begin{array}{l}\text { Polino- } \\
\text { mial }\end{array}$ \\
\hline $\begin{array}{l}\text { Variance - } \\
\text { Kurtosis }\end{array}$ & 100 & 99,75 & 99,75 \\
\hline $\begin{array}{l}\text { Standard } \\
\text { Error - } \\
\text { Entropy }\end{array}$ & 99,75 & 99,75 & 100 \\
\hline $\begin{array}{l}\text { Median - } \\
\text { SINAD }\end{array}$ & 100 & 100 & 100 \\
\hline
\end{tabular}

\section{Kesimpulan}

Penelitian ini memilih 9 dari 17 parameter statistik secara visual berdasarkan scatter plot nilai statistik data bantalan normal dengan data bantalan cacat lintasan luar. Tiga kombinasi parameter statistik yaitu Kurtosis-Variance, EntropyStandard Error dan Median-SINAD dipilih dari 9 parameter tersebut untuk dijadikan input classifier SVM. Kombinasi MedianSINAD menghasilkan tingkat akurasi paling tinggi untuk semua kernel (RBF, linier dan polinomial) yaitu $100 \%$ dengan lebar margin yang paling besar. Lebar margin berkontribusi pada kehandalan classifier terhadap variasi data sehingga potensi kesalahan klasifikasi menjadi minimal.

\section{Referensi}

[1]. Anoi, Y. H., Yani, A., \& Seto, B. A. (2019). Analisis Penyebab dan Perbaikan Vibrasi pada Fin Fan Blower F1-Ek-9D1 Milik PT. Badak LNG Bontang. TURBO, 48-55.

[2]. Kamiel, B. P., Mulyani, \& Sunardi. (2017). Deteksi Cacat Bantalan Bola Pada Pompa Sentrifugal Menggunakan Spektrum Getaran. Jurnal Ilmiah Semesta Teknika, 204-215

[3]. Fathurrohman, M., H, R. L., \& Susilo, D. D. (2019). Diagnosa Kerusakan Bantalan Bola Menggunakan Metode Support Vector Machine. Jurnal Mekanika, 14-21

[4]. Sakthivel, N., Sugumaran, V., \& Babudevasenapati, S. (2010). Vibration Based Fault Diagnosis of Monoblock Centrifugal Pump Using Decision Tree. Elsevier, 4040-4049

[5]. Perdana, R. M., Widodo, T. S., \& Litasari. (2010). Perancangan Sistem Pengolahan Isyarat ECG Untuk Diagnosis Menggunakan LabVIEW 2009 Berbasis Wavelet. Jurnal Penelitian Teknik Elektro, 231-236

[6]. Mahendra, I. G., Novamizanti, L., \& Atmaja, R. D. (2015). Deteksi Ada Tidaknya Cacat pada Kayu Menggunakan Metode Ekstraksi Ciri Statistik. e-Proceeding of Engineering, 58-68.

[7]. Luo, Y., Sun, H., Yuan, S., \& Yuan, J. (2015). Research on Statistical 
Characteristics of Vibration in Centrifugal Pump. Rev. Téc. Ing. Univ. Zulia., 49-61.

[8]. Suhardjono. (2004). Analisis Sinyal Getaran untuk Menentukan Jenis dan Tingkat Kerusakan Bantalan Bola (Ball Bearing). Jurnal Teknik Mesin, 39-48

[9]. Adi, F. R., \& Suwarmin. (2017). Identifikasi Keausan Bantalan Tirus (Tapered Bearing) Berbasis Analisis Vibrasi dengan Metode Support Vector Machine (SVM). Jurnal Teknik ITS, 768-771

[10]. Apriansyah, J. A., Suryadi, D., \& Suryono, A. F. (2017). Kajian Eksperimental Cacat pada Bantalan Berdasarkan Level Getaran. Teknosia

[11]. Damayanti, F., Arifin, A. Z., \& Soelai, R. (2010). Pengenalan Citra Wajah Menggunakan Metode TwoDimensional Linier Discriminant Analisist dan Support Vector Machine. Jurnal Ilmiah Kursor, 147-156.

[12]. Honakan, Adiwijaya, \& Faraby, S. A. (2018). Analisis Dan Implementasi Support Vector Machine Dengan String Kernel Dalam Melakukan Klasifikasi Berita Berbahasa Indonesia. $e$ Proceeding of Engineering, 17011710

[13]. Susilo, D. D. (2008). Deteksi Kerusakan Bantalan Gelinding pada Pompa Sentrifugal dengan Analisis Sinyal Getaran. Mekanika, 42-53 